Article

\title{
How Job Sharing Can Lead to More Women Achieving Senior Leadership Roles in Higher Education: A UK Study
}

\author{
Emma Watton ${ }^{1, *}$, Sarah Stables ${ }^{2}$ and Steve Kempster ${ }^{1}$ \\ 1 Department of Entrepreneurship and Strategy, Lancaster University Management School, \\ Lancaster University, Lancaster LA1 4YX, UK \\ 2 Stables and Co Innovation Limited, Windermere LA23 1HQ, UK \\ * Correspondence: e.watton@lancaster.ac.uk
}

Received: 12 April 2019; Accepted: 19 June 2019; Published: 5 July 2019

\begin{abstract}
This article explores the opportunity that job sharing offers as a way of encouraging more women into senior management roles in the higher education sector. There is a scarcity of female leadership representation in the higher education context, in particular a lack of female leadership pipeline. The article examines the underlying influences that limit the representation of women in leadership roles. To address these contextual limitations the process of job sharing is offered as a possible solution for harnessing the skills and talents of women in leadership positions in higher education and enabling the development of a leadership pipeline. To illustrate how such job sharing could occur the article provides a detailed vignette of a job share between two senior women leaders within a single UK university context and the positive impact this had on the organisation, the individuals and their leadership development. This article seeks to make a contribution by exploring how leadership job sharing can occur and sets out some recommendations for the adoption, negotiation and establishment of job share structures in the future.
\end{abstract}

Keywords: job sharing; leadership; women in higher education; co-constructed autoethnography

\section{Introduction}

There is a deepening issue of a scarcity of female leadership representation in the higher education sector (Morley 2013), an issue exacerbated by a recent culture of uncertainty caused by multiple and repeated structural reorganisations (Parsons and Priola 2010; Burkinshaw and White 2017). Indeed, Shepherd (2015) alludes to the detrimental impact changes in recruitment practices have had on women attaining senior roles. This article focuses on the opportunity afforded by job sharing as a practical way of promoting women's leadership, through the retention of female skills and experience, which in turn encourages the advancement of women into leadership positions in the higher education sector whilst also promoting increased business effectiveness. This research explores a single job share relationship between two women working at a senior level in a UK higher education setting. The argument in this article closely aligns with the work of Burkinshaw and White (2017) who proposed that in addition to, or perhaps instead of, programmes that fix women's agency a focus needs to be on 'fixing the University' as a method of increasing female representation in leadership roles across higher education. We will briefly review female leadership representation of the UK and international HE sectors, before further considering the position in the UK private sector. The inclusion of the private sector is beneficial for three reasons. Firstly, the job share role holders both held leadership roles in their late 20 's in the private sector and it was where one of the authors first undertook a job share role two decades earlier. Secondly, it is often the private sector that advances and develops innovative 
organisational practices (Leslie et al. 2016). Finally, the private sector has historically published data on women in senior leadership roles, in part due to the necessity of this through the Financial Times Stock Exchange (FTSE) reporting requirements which were initiated in 1999. We will highlight the opportunity that job sharing can create as one way of increasing women's representation in all sectors whilst focusing on the HE sector in particular. After considering contexts, the paper continues with six findings drawn from a job share experience. We then consider the findings using three levels of analysis in our discussion; before concluding the paper with limitations and suggestions for further research.

Whilst the new culture of the contemporary managerial university should in theory have broken down old entrenched structures, increasing public accountability and female representation, the recent prominence of financial constraints and associated multiple reorganisations (Acker 1990; White et al. 2011; Burkinshaw and White 2017) has reinforced gender inequalities rather than reduced them (Parsons and Priola 2010) cited in (Burkinshaw and White 2017). It is argued that the current situation has reinforced, rather than reduced, gender inequalities (Parsons and Priola 2010) cited in (Burkinshaw and White 2017). Of further concern is that women leaders faced with the long working hours culture, job uncertainty and an entrenched male leadership community of practice seem to be making a conscious decision to not apply for senior leadership roles thus further reducing the pipeline of female leaders (Burkinshaw and White 2017; Morley 2014; Shepherd 2017).

\subsection{The Higher Education Context}

We would first like to consider female representation within the UK HE context in more detail. The report 'Women Count: Leaders in Higher Education' (Jarboe 2018) provides analysis of the representation of women in leadership roles from $173 \mathrm{UK}$ universities. The report found some positive trends in the most senior leadership roles, whilst identifying negative trends in the number of women in roles considered to be the pipeline for future leadership. Positive trends included an increase in the proportion of female Chairs of Governing bodies, from 19\% in 2016 to 27\% in 2018 and in Vice-Chancellors from $22 \%$ in 2016 to $27 \%$ in 2018. More broadly the report found that $40 \%$ of governing body members and a majority of governing bodies are now gender balanced with $40 \%$ to $60 \%$ women members. Less positive is that the percentage of women leading academic faculties or schools has not grown since 2016 (31\%). The report identified a potential 'professorial roadblock' with only $24.6 \%$ of professors in 2016-2017 being women; this has subsequently increased to 26\% in the 2017-2018 academic year (Higher Education Statistical Agency 2017). This is a concern due to the requirement that a previous career in research and subsequent professorial appointment is a pre-requisite for a Vice-Chancellor appointment. Of further concern is the lack of diversity with only 25 black female professors in the UK (Rollick 2019). The lack of a female professorial leadership pipeline is echoed in findings across Europe. The 'Accelerating Gender Equality in Irish Higher Education Institutions' Report (The Gender Equality Taskforce 2018) found that female professors numbered 24\% in 2017. This report identified the numbers of female professors in 2016 from across Europe: France, 24\%, Germany, 23\%, Switzerland, 21\% and 29\% for Norway in 2017.

Internationally the figures are similar. The 'WomenCount: Australian Universities' report (Jarboe 2016) found that $25 \%$ of level E professors were women. A study by the American Council for Education (Johnson 2017) found that 32\% of professors in 2015 were female, higher than the European equivalent institutions. The report augments the pipeline debate as its findings show that female leaders are available, they are gaining academic qualifications and they do hold lower level faculty academic positions, however they consistently do not attain the senior positions associated with more prestige, money and power (Johnson 2017).

\subsection{The UK Private Sector Context}

The under representation of women in senior leadership roles and a drive towards gender balance is not solely the preserve of the higher education sector (Jarboe 2018). With an emphasis on impact and engagement the role of the civic university has increased the permeability between higher education 
and the private, public and voluntary sectors. Teaching, research and knowledge exchange are valued as ways to enhance professional experience. It is therefore beneficial to contrast the representation of women in senior roles within the UK private sector with those in higher education. The FTSE Board Report (Vinnicombe et al. 2018), coincidentally titled 'Busy going nowhere with the female executive pipeline' recognised that after many years of progress in board representation, for the first time in 2018 there were concerns over the pipeline of female leaders in the FTSE 250 results. Whilst the report findings showed that since October 2017 there had been a positive increase in the number of women on FTSE 100 boards from $27.7 \%$ to $29 \%$, over the same period there had been only a marginal increase from $22.8 \%$ to $23.7 \%$ in the FTSE 250 board representation.

In terms of women's representation on FTSE 100 boards in the UK, there have been some significant recent milestones. For example, the 29th October 2015 was a key moment as this was the first time there were no longer any male only boards (Sealy et al. 2016). However, this situation has not yet been achieved with the FTSE 250 companies, and in 2018 there was an increase in male only boards in the FTSE 250 companies list (Vinnicombe et al. 2018).

The FTSE, has a target of 33\% female board representation by 2020; however, as with the higher education sector there are concerns about the lack of a pipeline of women at senior management levels. Vinnicombe et al. (2018) suggested that the focus should be broadened to include a talent pipeline to reach and maintain true gender representation. We suggest that leadership job sharing is a useful and practical method for the retention of female talent and skills and broadening of the pipeline.

\subsection{The Emerging Opportunity for Job Sharing}

Job sharing can be defined as the voluntary sharing, between two or more people, of a full-time position. Unlike with some part time roles, a job share role retains all of the benefits of a full time position (Walton 1990).

Job sharing would seem an appropriate way to enable women (and of course men) to be retained or recruited into senior management roles when the need to work more flexibly is valued (Daniels 2011; Saunders and Bassett 2017), for example after the birth of children, whilst caring for family members or whilst studying part-time.

The 'Hours to Suit' report published by the charity Working Families (2007) highlighted the advantage of having two heads over one, together with wider benefits for example increased team diversity, increased productivity, innovation in HRM practices and process improvement. Similarly, the Job Share Project (Daniels 2011) considered how organisations could implement job sharing at a senior level and what the advantages of this are.

Evidence from both the Working Families report and the Job Share Project indicates that although the numbers of job share applications has increased in recent years, the take up rate is low. Low adoption rates can be due to tokenism from employers who, because of legislation, offer family-friendly policies, but for whom the implementation is harder to achieve in practice (Gatrell and Swan 2008). For those women who do succeed in setting up job shares, the promotional pathway remains problematic (Eagly and Carli 2007; Gatrell and Swan 2008; Taylor 2013). Job sharing at a senior level is rarer still (Saunders and Bassett 2017). Crucially, it is often down to whether a role is considered to be suitable or unsuitable for job sharing (Sidaway and Wareing 1992). Whilst technical or more task orientated roles often pass the suitability test management roles often do not. Reasons for this rest on the more personal relationship side of a management role, duplication of effort within areas such as handover time and a lack of clarity around role accountability and responsibility (Sidaway and Wareing 1992; Saunders and Bassett 2017).

The low adoption rates for job sharing seem at odds with the desire from organisations to increase the female talent pipeline as we have highlighted. Yet many organisations and managers remain stuck with an outdated view of flexible working and particularly job sharing (Daniels 2011). Talking Talent (2015) interviewed 2500 working women in the UK and asked the question "What support would help reduce barriers to career progression?" $54 \%$ cited access to flexible working as critical. A subsequent 
Talking Talent report (Talking Talent 2018) interviewed 7000 working families and found that $57 \%$ working fathers also wanted flexible hours.

In an article entitled 'Flexible boss: In the eyes of the manager' Alves (2016) emphasised that to overcome the barriers it is important to understand and address the fears managers could have through support and a more complete understanding of both how the practice of flexible working (including job sharing) can work in reality, and why flexible working has a positive impact on productivity. There remains some division between those people who are proponents of job sharing and those who view it as weak management. Yet the Agile Future Forum research has analysed that the value of people working in different ways can be a 3\% to $13 \%$ saving on workforce costs, and up to an $11 \%$ increase in sales revenue (Cannon and Elford 2017).

To summarise then, the business case for gender equality and diversity seems beyond question, with commercial evidence of increased productivity such as "gender balance in executive teams is one of the top productivity drivers, worth about 100B per year" (Anne Francke, Chief Executive, Chartered Management Institute, quoted in (Vinnicombe et al. 2018). We have considered contextual aspects for the UK HE sector and similar international countries HE sector together with data from the UK private sector. We have outlined the opportunity that exists for job sharing to be a way of encouraging more women into senior leadership roles. Next, we will go on to consider job sharing in practice within a UK university context, through research undertaken by two of the authors of this article, who were job shares of a senior management role.

\section{Materials and Methods}

Two of the authors, Emma and Sarah, undertook a job share for three years. This became a valuable learning experience for them both and as such they were interested in analysing the leadership and organisational implications that would enable others to see the possibilities of supporting more of these types of roles. Our research questions were therefore:

1. How can leadership be enacted as a job share?

2. What are the organisational implications of a leadership job share?

\section{Research Context}

The data collection approach was through narrative inquiry. This focused on a series of events during the three years of the job share. It is autobiographical, with Emma and Sarah writing and sharing a series of nine letters that explored the personal experience story in more detail. Clandinin and Connelly (2000) observe that although autobiographical writing enables the capturing of a small slice of time and a particular event, it illuminates other aspects of the writer's life for example, family life, education, parental influences and values.

The use of letters also enabled the authors to make sense of the experience per se and in relation to others. In part it helped to maintain the relationship through a personal tone (Clandinin and Connelly 2000). The letters enabled a process of reflexive dialogue between Emma and Sarah over a period of time. This process enabled them to make sense of their lived experience and with these dialogues anchored in practice (Cunliffe 2002).

The letter writing became a form of co-constructed autoethnography (Kempster and Stewart 2010) through the process of writing, reading and replying over an extended period. Clandinin and Connelly (2000, p. 106) posit that when one person writes a letter to another person there is the expectation of a reply, it becomes a 'give-and-take conversation'. This conversational tone richly captured the job share experience between Emma and Sarah at an authentic level. Due to the trusted relationship that they had developed the letters proved an invaluable way to access below the surface (Kermode 1980) aspects of their relationship through the reframing and interpretation of their experience of the job share. 
The data analysis approach used thematic analysis. Thematic analysis is a useful method of analysis for qualitative data, allowing patterns to emerge that are deemed to be important to the phenomenon under investigation (Fereday and Muir-Cochrane 2006). This method shares similarities with both grounded theory and content analysis (Floersch et al. 2010). Through the careful reading and re-reading of the data, pattern recognition allowed themes to become the categories of analysis (Fereday and Muir-Cochrane 2006).

Our process for the thematic data analysis was for Emma and Sarah to independently look for patterns in the letters. Using coloured pens they highlighted dominant themes across all nine letters. These dominant themes were then compared during face to face meetings. Overall there were very few differences with the colouring and identification of the dominant themes. The few variations were discussed between Emma and Sarah during the meetings and consensus quickly achieved for the final list of significant themes. Initially a list of seventy-six items of significance was created on a spreadsheet; further re-reading of the data and discussions regarding the seventy-six items reduced this to six core themes or findings as we will describe below. The frequency of each of the six themes occurring in all of the letters was then calculated. Emma and Sarah then ranked the six themes in order of importance based on their experience. Table 1 below shows the six themes, their frequency and lists them in rank order.

Table 1. Analysed theme titles and rank order.

\begin{tabular}{llc}
\hline \multicolumn{1}{c}{ Themes in Rank Order } & $\begin{array}{c}\text { Frequency of } \\
\text { Occurrence in the Data }\end{array}$ \\
\hline $\begin{array}{l}\text { 1. } \\
\text { Play to one another's strengths - leverage the benefits of a job share at } \\
\text { an individual and organisational level. }\end{array}$ & 5 \\
\hline 2. $\quad \begin{array}{l}\text { Create the right environment both physically and emotionally in } \\
\text { which to perform to your best. }\end{array}$ & 12 \\
\hline 3. $\quad \begin{array}{l}\text { Establish solid foundations up front about setting up and ending the } \\
\text { job share. }\end{array}$ & 10 \\
\hline 4. $\quad \begin{array}{l}\text { A job share can make a senior leadership role more tenable by } \\
\text { shouldering responsibility and complexity with another person. }\end{array}$ & 15 \\
\hline 5. & $\begin{array}{l}\text { Having empowerment, trust and faith in one another's ability to } \\
\text { complete tasks individually whilst at the same time having sufficient } \\
\text { knowledge to be able to pick up work for one another when needed. }\end{array}$ \\
\hline 6. $\quad$ Being humble whilst at the same time being one another's biggest fans.
\end{tabular}

The full list of themes can be found in Appendix A.

\section{Results}

We introduce the results by first presenting the background to the host organisation, and we then explore the role that was negotiated. The detailed results are drawn from the job share itself over the three-year period as analysed by the role holders. We then move on to discuss these results in light of the existing literature and theories.

At the time of the study the host university had significantly higher levels of female representation at both board and senior management levels than the average for the HE sector. As of April 2019, the website published make-up of the board of Directors or Vice-Chancellor's Executive as: $62 \%$ female, and the broader senior leadership teams is $77 \%$ female. The above average female management representation may be a combination of the following factors: It is a young organisation (having been formed in 2007); it has had significant change in senior management roles over its first 10 years; it has 
at its heart programmes anchored in health and education (academic disciplines which have a higher proportion of women in senior roles). Despite the turbulent nature of the sector in recent years many of the environmental factors and cultures that have contributed to gender inequality in the sector, such as 'the old boys' network' and entrenched hierarchical structures have not been manifest at the host university. Further, the host university has always prided itself on its proactive approach towards equality and diversity, for example, becoming one of the first UK Universities to become a Stonewall Employer in 2007. Of significance for this article Sarah and Emma's perception was that the university had a proactive and enabling approach towards flexible working and they were therefore confident in applying for the role as a job share.

From the letter writing data analysis Emma and Sarah identified from their experience six themes which are presented here as findings. We will illustrate our findings through the narrative accounts between Emma and Sarah and elucidate how the job share developed over the three years with significant events drawn directly from practice. The findings are presented in chronological order rather than the ranked order shown in Table 1 to give a sense of an unfolding appreciation of the job share.

\subsection{Finding \# One: Establish Solid Foundations up Front about Setting up and Ending the Job Share}

Very often a job share is set up without considering the detail of how it will work on a practical, day to day basis for example who will work which days? Is there a handover day? If so when? It is of equal importance to consider how a job share might end. During a previous job share that Emma had undertaken there had been no explicit consideration of the job share ending and this was prominent in Emma and Sarah's thinking for their new arrangement. Their discussions began before Sarah had commenced her maternity leave with her second child with Emma covering Sarah's full time role during the 12 months of Sarah's maternity leave.

"The need to have maternity cover was obvious and ... you were always my first choice ... you accepted the role... and I left with an understanding that we would discuss and consider job sharing on my return".

However, whilst Emma and Sarah felt that a job share would be a workable solution to Sarah returning from her maternity leave decision makers at the university were initially reluctant to accept the proposal and the application was refused. The reason stated was that the role was considered unsuitable for a job share arrangement due to its seniority. Sarah describes this situation in more detail:

"We began to engage with the return to work process and the process for application of the job share ... In retrospect perhaps the fact that the Dean said no initially was actually a good thing for many reasons, the preparation time for the meeting actually clarified for us the 'contract' we were making and taking the time to clearly articulate this was very important".

At the second application Emma and Sarah's job share was approved, initially on a six month trial basis. It would continue for three years with Emma and Sarah taking on increasing levels of responsibility in their role for example, covering for the Associate Dean for Enterprise when that role became vacant for six months. We will return to the conclusion of the job share towards the end of the findings section.

The lack of initial support for the job share role concurs with evidence from Shepherd (2017) that universities are conservative and try to minimise risks wherever possible, despite of course, operating in a highly challenging and competitive environment. It also aligns with a suggestion from Williams (2000) that whilst many organisations offer job sharing on their job application forms there is little encouragement for applications to be made. 


\subsection{Finding \# Two: A Job Share Can Make a Senior Leadership Role More Tenable by Shouldering} Responsibility and Complexity with Another Person

During Sarah's maternity leave the Faculty Enterprise Manager role underwent a rapid period of evolution. The amalgamation of faculties meant that the new role holder was responsible for three former faculties rather than one. This meant the line management responsibility and income and expenditure accountability had increased significantly. Emma became progressively stressed and unhappy about how tenable the new role was.

"It was starting to become too much; I felt really alone a lot of the time doing the [maternity cover] role-the people close to me had gone or were going; I was beginning to count day the days to when you would come back-I didn't think I could carry on doing the role as it was anymore".

Equally in Sarah's reply to Emma she highlighted her concern about coming back to work full-time:

"A bleak outcome as I was then faced with either a full time return to work or handing my notice in. If pushed I would have said no and handed my notice in".

For both Sarah and Emma a job share became a workable solution to a demanding job which would enable the retention of them both.

A combination of work load and managerial demands coupled with the nature of the role are two of the main stressors identified in the HE sector (Daniels and Guppy 1994). A job share at a senior level is therefore one way of mitigating this risk. Human capital differences are often one of the conflicts women face in balancing their work and home roles, particularly with the desire to care for children through part time employment (Northouse 2007). Often for women, as their career progresses being hard-working and single-minded in their achievements becomes stressful and unsustainable because of family demands and expectations on them drawn from the familial context competing with the work context (Sinclair 2007). Morley (2014) also noted the dilemmas women often face in juggling their professional and domestic responsibilities.

\subsection{Finding \# Three: Create the Right Environment Both Physically and Emotionally in Which to Perform to} Your Best

Sarah was new to job sharing as a way of working whereas Emma had undertaken two job shares previously, one in the private sector and one within a different UK university. From these experiences Emma was aware of the need to prioritise establishing a conducive environment for the job share as this was fundamental to the success of the partnership. This not only covered the physical aspects such as a shared office but included the equally important emotional dynamic, Sarah was able to explain the benefits of a conducive environment:

"I know I am a different person now from then, I know that I am a better leader and line manager, I know that I am far calmer and can handle previously stressful situations at a more senior level... at stressful times my blood pressure would drop if I heard your voice".

When the right environment is achieved performance is maximised. A number of performance outcomes such as motivation, commitment, continuity, energy are increased through a job share compared to those achieved by a single full time employee (Walton 1990; Daniels 2011). From a leadership learning perspective an agreeable environment connects with the importance of tacit learning through participation with leaders observing and learning vicariously from one another (Kempster 2009). In a sense the job share created multiple opportunities for Emma and Sarah to learn from one another.

\subsection{Finding \# Four: Play to One Another's Strengths_Leverage the Benefits of a Job Share at an Individual and Organisational Level}

Emma and Sarah came from quite similar family backgrounds; they both had successful careers in the private sector in the 1990's before moving into higher education in the 2000's. Emma's first career 
was as a small business bank manager and Sarah was a European business development manager in the telecommunications industry. Although they had complementary skill sets, there were, in addition, a number of skills unique to each of them. Emma explains when they realised whilst undertaking the job share the benefit of having a combined skill set.

"Even though we are similar in lots of respects we have a good balance of skills and some things that we liked doing more than others. So finance meetings and detail was something that you really liked doing ... I liked doing some of the written reports or papers we had to submit to [name of Dean] each month... The other time we realised the full extent of our strengths was for the second restructure and the revised job description that came out for our post-between us we were able to meet all of the essential criteria-singly we couldn't demonstrate it as well".

A similar finding was described by Walton (1990) on the increased skill level that can be achieved through job sharing. Further, the highly challenging and rapidly changing world means that many contemporary management positions being advertised are unlikely to have all of the essential and desirable skills met by one person (Saunders and Bassett 2017). The UK's Resource Connection and the Industrial Society (Daniels 2011) estimate that there is a 30\% productivity enhancement that can be gained through two people job sharing. This productivity enhancement through combined strengths affords benefits to both the job share role holders and the organisations themselves. For women who consider a job share role there is the opportunity to validate and identify their own strengths in leadership which in turns enables them to progress further in the future (Sinclair 2007).

3.5. Finding \# Five: Having Empowerment, Trust and Faith in One Another's Ability to Complete Tasks Individually Whilst at the Same Time Having Sufficient Knowledge to Be Able to Pick up Work for One Another When Needed

One of the greatest strengths of Sarah and Emma's relationship was the trust and faith they placed in one another to carry out the role to a high standard. They both shared very similar values and beliefs and knew the importance of making the job share a success for themselves and the institution. Both felt that the job share experience was fundamental in developing their confidence for the increased job responsibility post re-structure. Emma describes this as:

"We think along very similar lines, any decisions we made ... one of us singly would have made... The team and other people at the Uni wouldn't have been able to tell who had made the decision and of course for large amounts of time especially over video conference people couldn't tell us apart-we stopped quite early on correcting people when they got our names wrong as it didn't matter to us".

In Sarah's reply she comments on the importance of finding the right fit in terms of a job share and the bond that is created:

"Job sharing is both tricky and wonderful if done properly with the right person. There has to be an overriding commitment to the other person, huge amounts of loyalty and respect are essential".

Sarah continues by describing the development of her leadership identity through the job share experience:

"One thing is true I have grown, I am more confident; I am more certain of who I am as a result of having you as my job share".

For female leaders there is often an emphasis on the importance of relationships and a people orientation (Chesterman et al. 2003). Jackson and Parry (2011) called for more feminisation in leadership whether the leaders are male or female. An increase in confidence helps to counter some of the gender stereotype-based expectations between men and women with men typically stereotyped with agentic characteristics such as confidence and assertiveness and the risk women can face in not conforming to expectations (Heilman 2001). Further, women leaders often have less self-confidence when compared 
to men (Hoyt 2010), despite women very often placing significant expectations on themselves in terms of standards and levels of work (Redmond et al. 2017). This lack of confidence is one of the factors inhibiting women's career progression (Manfredi et al. 2014). Mentoring is one way that a lack of confidence is often addressed (Shakeshaft et al. 2007). The benefits of having role models (Hoyt and Johnson 2011) is a helpful mechanism to enhance confidence for women. Both mentoring and using role models enable women to develop a shared, trusted relationship through a personal support mechanism (Redmond et al. 2017). In a sense a senior leadership job share creates this type of relationship in a naturlistic manner and it is more readily available and accessed through day to day interactions.

\subsection{Finding \# Six: Being Humble Whilst at the Same Time Being One Another's Biggest Fans}

Emma and Sarah had known one another for five years through the roles that they had undertaken prior to the maternity cover and job share role. These relationship foundations were important in ensuring that they already respected one another's work ethic and approach. This high level of reciprocal esteem continued during the job share and through this relationship. This enabled both to promote one another's strengths to other stakeholders. Neither Emma nor Sarah were comfortable with self-promotion as this did not come naturally to them, their default was more one of humility. Emma captures this in her letter to Sarah:

"I would lose track of all of the times you promoted me to others ... neither of us are good and confident about ourselves but we felt able to speak up for one another".

Sarah spoke about how the job share enabled a duality of development:

"Jealousy is an ugly emotion and one that luckily my sense of loyalty to you always overrode. I think that has also been a very important lesson, allowing others to excel means we all take a huge step forward".

The matter of women not self-promoting and or considering negotiation regarding their role or for example, salary increases is again an area of difference when compared with men (Northouse 2007). Women often feel more able to use self-promotion when this is augmented by personal achievement (Fitzsimmons et al. 2014). Putting oneself forward for women requires more deliberate planning (Black and Islam 2014). One of the unexpected outcomes of a job share is that it may help to address this self-promotion deficiency in women.

Finally, let us return to finding number one about the importance of being clear about the ending of the job share role. The informal contract and commitment between Emma and Sarah was for the job share to be for approximately three years, this being the time before Sarah's second child started pre-school. Whilst not set in stone the position did in fact last for this period and then Emma secured an academic post at another university. Emma describes the process of ending the job share relationship:

"Again it's difficult to know when the end started to become inevitable. I think for me it was a whole combination of factors - none of them though related to you or the job share... I remember I had made a promise to you that I would tell you first about the [name of University] job before I told anyone else-it had the most impact on you so it seemed only fair ... we carried on almost as if nothing different was about to happen. Of course we both knew it was but we pretended it wasn't or that it would be a bit like me going on holiday".

After Emma left, Sarah decided she would like to carry on with a job share relationship and Emma's vacancy was advertised and filled.

\section{Discussion}

The narrative analysis of Emma and Sarah's job share has identified six themes. Integrated together these broadly illustrate how a leadership job share can occur and the prominent aspects of such a leadership process. Our discussion will focus on three levels. On one level, a research level, that 
provides a useful contribution in terms of opening avenues of research to explore the phenomenon of leadership as a job share. Aspects identified in our themes provide a platform for further research, however there would be many other elements of leadership job sharing that warrant consideration. For example: To examine aspects of identity construction occurring between the two in the job share. Within the leader-follower relationship; the impact of different attributions from followers with regard to the qualities, skills and behaviours of the job share leadership. Performance management incidents of one of the leaders and the impact on the other leader and consequential management of followers. The moral conduct of one or both of the two leaders within the extended leader-follower relationship and the consequential impact. The politics and differential emotion management of followers between the two job-share leaders. In essence a leadership job-share is a complex phenomenon. However, the aspects we have identified illustrate how the leadership job-share can be handled in a manner and context that provides a frame from which other leadership job-shares can be analysed and compared.

The second level of analysis of our themes and data is toward the policy implications. We have shown earlier in the paper the range of gender inequality aspects that are prevalent in the HE context. A leadership job-share provides a mechanism by which such management inequality can be purposefully addressed. We suggest it has the very real potential for a positive impact on gender equality in the workplace both from an employee and employer perspective. There is a clear need for organisations and in particular, universities to address some of the structural limitations, or as Burkinshaw and White (2017) allude to, the need to 'fix the universities' to enable more women to achieve senior leadership roles. Our policy discussion therefore focuses on the opportunity for more job share roles to be created at a senior level through strategic structural enablers within the HE sector. The structural enablers we describe our based on Emma and Sarah's reflections on their experience of securing a job share position at a senior level and how HEIs could create a more conducive environment to encourage and support job share roles.

Building on finding number one concerning the foundations for a job share, there appears to be a strong case for organisations to actively endorse the vast majority of posts as suitable for job sharing, this may then lead to an increase in the take up of job share positions (Williams 2000). We would assert that this has a very strong likelihood for a positive impact on the female leadership pipeline, which in turn would achieve gender equality at senior levels over time. We suggest it is highly plausible that if universities adopted job sharing at all levels their ability to both retain existing talented women and recruit more talented women would likely be increased. The HE sector has a responsibility not only to eliminate some of the barriers that exist for women (Stead 2013) but to create more appropriate organisational structures (Redmond et al. 2017). Additionally, universities might be well placed to focus on what Shepherd (2017) describes as the minutiae politics and cultural traditions that underpin the current practices and procedures in HR departments. By positively embracing job sharing, roles could be flexibly designed to focus on business impact (Saunders and Bassett 2017), and help address the range of complex roles that are now required (Thude et al. 2017) in the HE context. Appropriately designed leadership job share roles would help impact on the pervasive and prevalent situation whereby women are twice as likely as men to not succeed in their applications for senior management roles in HE (Shepherd 2017). Increased success of such applicants through well designed job-share roles would enhance much needed diversity at this level, would help change the leadership stereotype and homo-sociability that persists in the sector (Coleman 2012).

Linked to finding number three is the role that observational learning through leadership role models plays (Kempster 2009). This is a further structural enabler open to the HE sector. By women being partnered with senior leaders (irrespective of gender) the championing of senior leadership roles could occur (Black and Islam 2014). Elmuti et al. (2009) highlight the scarcity of female role models in the sector. Linking up the leadership job-share with male leaders may provide a useful stimulus to leadership development. Equally there may be tensions and disquiets through social comparison and this can similarly be developmental-negative notable others have been shown to stimulate development in terms of what to become in comparison to what not to become (Kempster 
2009). It is also important for women's leadership development to connect with women role models outside of HE (Stead and Elliott 2009). Connecting outside an organisation, for example utilising social networks, can afford environments that provide emotional support, professional socialisation and social capital building (Coleman 2011) that provides encouragement for women to apply for senior roles, and indeed push for job-share roles_-as was the case with Sarah and Emma. In this way mentors and networks would mitigate the suggestion by Johnson and Mathur-Helm (2011) that women can have a tendency to not fully support one another.

The third level of analysis linked to our data themes is the opportunity for job sharing to be a powerful leadership development tool, as highlighted through Sarah and Emma's experience. The sense-making and reflective learning that occurs as a result of the job share relationship are akin to the more formal (and costly) HE women's leadership development programmes such as the Aurora Programme (https://www.lfhe.ac.uk/en/programmes-events/equality-and-diversity/aurora/) offered through the Leadership Foundation. Rather than these types of programmes 'fixing the women' (Burkinshaw and White 2017) a subtler approach would be for regional universities to create informal leadership development opportunities. For example, women engaged through activities such as action learning, leadership exchanges, social networking events, even prospective job share partners speed dating! Schemes such as this would help to address the challenge for women from non-academic backgrounds entering the unknown realms of senior management HE Hoskins (2013).

Of significance for this special issue is our substantive finding and contribution, that leadership roles in HE can be shared. This perhaps challenges the espoused leadership ideal of a single leader being responsible for vision, sense-giving and direction setting (Reid and Karambayya 2009). Mintzberg (1989) argued that dual leadership is problematic unless both leaders can operate as if they are a single entity. Many other industries such as journalism, banking and healthcare seem to be more advanced in their adoption of dual leadership roles (Thude et al. 2017). HE could learn from these existing advocates. By creating senior leadership job shares we might at a stroke increase the numbers of women achieving these positions and enable a tipping point to be reached.

However, the authors recognise that their suggestions for implementation need careful handling if sustainable success becomes the prominent narrative. Emma and Sarah were extremely fortunate in that they were able to choose who to job share with and that the quality and equality of their relationship was well established. There are examples of job share failures where there is incompatibility between the post holders, a lack of communication, a breakdown in trust or a power imbalance (Thakur et al. 2018). A breakdown in the job share relationship appears to lead to a reduction in productivity levels (Walton 1990). Of importance here is the need for organisations to be willing to adopt job sharing and negotiate the position with the successful candidates to ensure that the benefits are clearly established for all concerned.

\section{Conclusions}

This article has sought to capture the essence of a three-year hybrid job share experience of two women working in a senior managerial position within a UK HE context. Over the period of the job share a number of benefits from an employee, employer and leadership development perspective became manifest and have been highlighted. The multiple benefits of performing a leadership role through a job share, for women in particular, affords an opportunity to encourage more employees and employers to consider job sharing at a senior level as a way of retaining, growing and developing leadership capability within organisations.

It should be noted that as a single example of a job share relationship within the UK this research is limited and further research of other job share relationships in the HE sector would be highly desirable. Indeed there is a lack of research into job shares in practice and we would therefore recommend that further studies are carried out to identify both the strengths and weaknesses of this way of working. Having more high profile job sharing relationships would be beneficial in breaking down some of the 
barriers and misconceptions about how job shares work. From our experience not only can leadership be shared but we would argue that leadership can be more successful as a result of a job share.

Author Contributions: E.W. and S.S. collected and carried out the data analysis for this article jointly. E.W. wrote the methods and results sections of the paper. E.W. co-wrote the introduction, discussion and conclusions sections of the paper. S.S. was responsible for the statistical information gathering and for identifying relevant research reports into job sharing. S.S. co-wrote the introduction section of the paper. S.K. advised on the data analysis approach. S.K. co-wrote the discussion and conclusion sections of the paper.

Funding: This research received no external funding.

Acknowledgments: The authors would like to acknowledge and thank Liz Beaty the former Pro Vice Chancellor at the host university. Liz became an advocate of the job share between Sarah and Emma and whilst the three of them were sharing a pizza one evening after work, encouraged the authors to use letter writing as the methodology to capture their job share relationship. The authors further acknowledge that Liz, being in a senior role at the University was a role model for them at this time.

Conflicts of Interest: The authors declare no conflict of interest.

\section{Appendix A. Full List of Themes and Core Themes}

\begin{tabular}{|c|c|}
\hline Informal Items of Significance & Themes \\
\hline Identification of a potential job share partner & $\begin{array}{l}\text { 3. Establish solid foundations up front about setting } \\
\text { up and ending the job share. }\end{array}$ \\
\hline Honesty over previous experience both good and bad & $\begin{array}{l}\text { 3. Establish solid foundations up front about setting } \\
\text { up and ending the job share. }\end{array}$ \\
\hline $\begin{array}{l}\text { Self-sacrifice for the benefit of the other person and } \\
\text { the team }\end{array}$ & $\begin{array}{l}\text { 6. Being humble whilst at the same time being one } \\
\text { another's biggest fans. }\end{array}$ \\
\hline $\begin{array}{l}\text { Initial discussions of why need to be realistic and } \\
\text { honest }\end{array}$ & $\begin{array}{l}\text { 3. Establish solid foundations up front about setting } \\
\text { up and ending the job share. }\end{array}$ \\
\hline $\begin{array}{l}\text { Acknowledgment of the benefits of having two } \\
\text { people doing the job in terms of well-being. }\end{array}$ & $\begin{array}{l}\text { 2. Create the right environment physically and } \\
\text { emotionally to perform to your best. }\end{array}$ \\
\hline $\begin{array}{l}\text { Acknowledgment that working on your own was } \\
\text { problematic and working with the right person in a } \\
\text { dual leadership role would solve that. }\end{array}$ & $\begin{array}{l}\text { 4. A job share can make a senior leadership role more } \\
\text { tenable by shouldering responsibility and complexity } \\
\text { with another person. }\end{array}$ \\
\hline $\begin{array}{l}\text { Office set up-shared office, desks re-organised to } \\
\text { face each other. }\end{array}$ & $\begin{array}{l}\text { 3. Establish solid foundations up front about setting } \\
\text { up and ending the job share. }\end{array}$ \\
\hline Benefits for each individual needs to be clear & $\begin{array}{l}\text { 3. Establish solid foundations up front about setting } \\
\text { up and ending the job share. }\end{array}$ \\
\hline Recognise individual strengths & $\begin{array}{l}\text { 1. Play to one another's strengths at an individual } \\
\text { and organisational level. }\end{array}$ \\
\hline Working hard for each other & $\begin{array}{l}\text { 6. Being humble whilst at the same time being one } \\
\text { another's biggest fans. }\end{array}$ \\
\hline Important to both of us to do a good job & $\begin{array}{l}\text { 6. Being humble whilst at the same time being one } \\
\text { another's biggest fans. }\end{array}$ \\
\hline Benefits for each individual needs to be equitable & $\begin{array}{l}\text { 3. Establish solid foundations up front about setting } \\
\text { up and ending the job share. }\end{array}$ \\
\hline $\begin{array}{l}\text { Lists created to help communication and progress } \\
\text { reporting }\end{array}$ & $\begin{array}{l}\text { 5. Having empowerment, trust and faith in one } \\
\text { another's ability. }\end{array}$ \\
\hline
\end{tabular}




\begin{tabular}{|c|c|}
\hline Informal Items of Significance & Themes \\
\hline $\begin{array}{l}\text { Foundations of trust built (implicitly) at early stages } \\
\text { because of commitment to doing the hand over } \\
\text { correctly }\end{array}$ & $\begin{array}{l}\text { 5. Having empowerment, trust and faith in one } \\
\text { another's ability. }\end{array}$ \\
\hline $\begin{array}{l}\text { Awareness of each other's feelings and a } \\
\text { determination to support each other }\end{array}$ & $\begin{array}{l}\text { 2. Create the right environment physically and } \\
\text { emotionally to perform to your best. }\end{array}$ \\
\hline $\begin{array}{l}\text { Awareness of the benefits and support in a job share } \\
\text { relationship }\end{array}$ & $\begin{array}{l}\text { 5. Having empowerment, trust and faith in one } \\
\text { another's ability. }\end{array}$ \\
\hline $\begin{array}{l}\text { Shared values and understanding of what is right and } \\
\text { what is wrong }\end{array}$ & $\begin{array}{l}\text { 5. Having empowerment, trust and faith in one } \\
\text { another's ability. }\end{array}$ \\
\hline $\begin{array}{l}\text { Sense making of an ethical dilemma leading to a } \\
\text { significant shift our confidence to deal with the } \\
\text { necessary response }\end{array}$ & $\begin{array}{l}\text { 5. Having empowerment, trust and faith in one } \\
\text { another's ability. }\end{array}$ \\
\hline $\begin{array}{l}\text { Making time to re-group and reflect key to sense } \\
\text { making }\end{array}$ & $\begin{array}{l}\text { 5. Having empowerment, trust and faith in one } \\
\text { another's ability. }\end{array}$ \\
\hline $\begin{array}{l}\text { Shared lived work experience enabled a critical friend } \\
\text { at a time of need leading to reflection and growth }\end{array}$ & $\begin{array}{l}\text { 1. Play to one another's strengths at an individual } \\
\text { and organisational level. }\end{array}$ \\
\hline A greater confidence in raising concerns and issues & $\begin{array}{l}\text { 5. Having empowerment, trust and faith in one } \\
\text { another's ability. }\end{array}$ \\
\hline $\begin{array}{l}\text { Two respected female voices having a greater power } \\
\text { than one isolated voice. }\end{array}$ & $\begin{array}{l}\text { 5. Having empowerment, trust and faith in one } \\
\text { another's ability. }\end{array}$ \\
\hline $\begin{array}{l}\text { Recognition of our own and each other's ability, } \\
\text { competency and experience gained validity }\end{array}$ & $\begin{array}{l}\text { 5. Having empowerment, trust and faith in one } \\
\text { another's ability. }\end{array}$ \\
\hline $\begin{array}{l}\text { Having each other to deal with a difficult senior } \\
\text { manager enabled us to handle the situation more } \\
\text { calmly, rationally and with less potential emotional } \\
\text { damage. }\end{array}$ & $\begin{array}{l}\text { 2. Create the right environment physically and } \\
\text { emotionally to perform to your best. }\end{array}$ \\
\hline $\begin{array}{l}\text { Combined previous experience meant we could } \\
\text { handle a difficult senior member of male staff who } \\
\text { used bullying behaviour to enact his decisions. }\end{array}$ & $\begin{array}{l}\text { 5. Having empowerment, trust and faith in one } \\
\text { another's ability. }\end{array}$ \\
\hline Similar thought processes and decision making & $\begin{array}{l}\text { 5. Having empowerment, trust and faith in one } \\
\text { another's ability. }\end{array}$ \\
\hline $\begin{array}{l}\text { Complete trust in one another to make the right } \\
\text { decision }\end{array}$ & $\begin{array}{l}\text { 5. Having empowerment, trust and faith in one } \\
\text { another's ability. }\end{array}$ \\
\hline $\begin{array}{l}\text { People couldn't tell us apart! We stopped correcting } \\
\text { people when they got our names wrong! }\end{array}$ & $\begin{array}{l}\text { 2. Create the right environment physically and } \\
\text { emotionally to perform to your best. }\end{array}$ \\
\hline $\begin{array}{l}\text { Utmost respect for one another, similar work } \\
\text { experience, similar ethics }\end{array}$ & $\begin{array}{l}\text { 6. Being humble whilst at the same time being one } \\
\text { another's biggest fans. }\end{array}$ \\
\hline $\begin{array}{l}\text { We looked out for one another and were confident } \\
\text { and went out of our way to promote one another (not } \\
\text { being confident to do this for ourselves). }\end{array}$ & $\begin{array}{l}\text { 6. Being humble whilst at the same time being one } \\
\text { another's biggest fans. }\end{array}$ \\
\hline $\begin{array}{l}\text { Played to one another's strengths (Sarah-finance } \\
\text { and detail, Emma-ball park finance and written } \\
\text { reports, presentations) }\end{array}$ & $\begin{array}{l}\text { 1. Play to one another's strengths at an individual } \\
\text { and organisational level. }\end{array}$ \\
\hline
\end{tabular}




\begin{tabular}{l}
\hline Informal Items of Significance \\
\hline Shared presentations and workshops built confidence \\
e.g., balanced scorecard and Henley Conference
\end{tabular}

Re-applied for role and shared skill set enabled the job share partnership to meet all criteria

Division of tasks was done around knowledge of each other's skill sets without discussion.

Never tried to outdo one another and always approached the situation with a view to it being equitable

Never competed with each other
Never let each other down as it was important to do it
for one another

Pushed ourselves to do new things

Received the VC award for excellence as recognition

Comfortable talking about job sharing with media reports, research students etc.

Lots of laughs usually at own expense to de-stress

Sufficiently attuned and relaxed to show vulnerability and weaknesses

Approach any situation with humility and humour

Giant lists were created and ticked off together

Huge amounts of loyalty and respect

\section{Themes}

5. Having empowerment, trust and faith in one another's ability.

4. A job share can make a senior leadership role more tenable by shouldering responsibility and complexity with another person.

1. Play to one another's strengths at an individual and organisational level.

6. Being humble whilst at the same time being one another's biggest fans.

6. Being humble whilst at the same time being one another's biggest fans.

6. Being humble whilst at the same time being one another's biggest fans.

5. Having empowerment, trust and faith in one another's ability.

1. Play to one another's strengths at an individual and organisational level.

2. Create the right environment physically and emotionally to perform to your best.

6. Being humble whilst at the same time being one another's biggest fans.

6. Being humble whilst at the same time being one another's biggest fans.

6. Being humble whilst at the same time being one another's biggest fans.

5. Having empowerment, trust and faith in one another's ability.

6. Being humble whilst at the same time being one another's biggest fans.

Acceptance of who we are and being comfortable with that.

2. Create the right environment physically and emotionally to perform to your best.

2. Create the right environment physically and emotionally to perform to your best.

health related and perhaps the potential for self-employment

Sarah received slot in of role because of maternity leave which was a benefit for Emma

2. Create the right environment physically and emotionally to perform to your best.

Maternity cover role was hard, recognition that a job share was a benefit.

4. A job share can make a role tenable.

KIT days at Sarah's house at kitchen table demonstrating an early permeability between work and home for Sarah and Emma

Emma chose to have coaching as a way of maintaining balance
2. Create the right environment physically and emotionally to perform to your best.

2. Create the right environment physically and emotionally to perform to your best. 


\begin{tabular}{ll}
\hline Informal Items of Significance & Themes \\
\hline $\begin{array}{l}\text { Did not choose to make a formal complaint because } \\
\text { we managed the situation }\end{array}$ & $\begin{array}{l}\text { 4. A job share can make a senior leadership role more } \\
\text { tenable by shouldering responsibility and complexity } \\
\text { with another person. }\end{array}$ \\
\hline $\begin{array}{l}\text { Utmost respect and the importance of the work-life } \\
\text { balance added to the bond we had }\end{array}$ & $\begin{array}{l}\text { 2. Create the right environment physically and } \\
\text { emotionally to perform to your best. }\end{array}$ \\
\hline $\begin{array}{l}\text { Discussed the end of the job share and the continuity } \\
\text { of our friendship from the beginning }\end{array}$ & $\begin{array}{l}\text { 3. Establish solid foundations up front about setting } \\
\text { up and ending the job share. }\end{array}$ \\
\hline $\begin{array}{l}\text { Emma understood that job share needed whilst Emily } \\
\text { was a baby }\end{array}$ & $\begin{array}{l}\text { 3. Establish solid foundations up front about setting } \\
\text { up and ending the job share. }\end{array}$ \\
\hline
\end{tabular}

Chicken pox cover demonstrated how we covered for each other when additional support was needed for home

We were rarely ill, which was a good sign that we 2. Create the right environment physically and
emotionally to perform to your best. were both healthy and our well-being was good.

2. Create the right environment physically and emotionally to perform to your best.

\begin{tabular}{l} 
Social activities and helping one another out of work \\
10. Self-denial and humility \\
\hline Emma made Sarah's children's Easter bonnet's for \\
their school competition \\
\hline Sarah's children started to inadvertently call Emma \\
'Mum'! \\
After [name of first child] Sarah needed to work for \\
financial reasons-could not face working full time as \\
she had done after first child
\end{tabular}

Feeling of failure as Sarah realised she could not work full time after [name of second child]

2. Create the right environment physically and emotionally to perform to your best.

2. Create the right environment physically and emotionally to perform to your best.

2. Create the right environment physically and emotionally to perform to your best.

4. A job share can make a senior leadership role more tenable by shouldering responsibility and complexity with another person.

4. A job share can make a senior leadership role more tenable by shouldering responsibility and complexity with another person.

Determination to work at a senior level and be a good parent

2. Create the right environment physically and emotionally to perform to your best.

Sarah did Emma's washing when her water ran out

2. Create the right environment physically and emotionally to perform to your best.

Sarah keen to ensure that the benefits for Emma were as recognised and in place from the beginning

4. A job share can make a senior leadership role more tenable by shouldering responsibility and complexity with another person.

Enabled to have career and years with children

4. A job share can make a senior leadership role more tenable by shouldering responsibility and complexity with another person.

Process of understanding what was valued most, throughout all that children are a priority.

4. A job share can make a senior leadership role more tenable by shouldering responsibility and complexity with another person.

Shared how we were feeling constantly this changed afterwards

2. Create the right environment physically and emotionally to perform to your best.

Previous experience of ending a job share had been painful which lead to an early discussion of how this might end

3. Establish solid foundations up front about setting up and ending the job share. 


\begin{tabular}{ll}
\hline Informal Items of Significance & Themes \\
\hline $\begin{array}{l}\text { The end started through a combination of factors } \\
\text { external to the job share }\end{array}$ & $\begin{array}{l}\text { 3. Establish solid foundations up front about setting } \\
\text { up and ending the job share. }\end{array}$ \\
\hline $\begin{array}{l}\text { Both applied for a job share role at Cumbria which } \\
\text { was delayed }\end{array}$ & $\begin{array}{l}\text { 4. A job share can make a senior leadership role more } \\
\text { tenable by shouldering responsibility and complexity } \\
\text { with another person. }\end{array}$ \\
\hline $\begin{array}{l}\text { Promised to tell me first about LUMS job out of } \\
\text { loyalty and respect }\end{array}$ & $\begin{array}{l}\text { 6. Being humble whilst at the same time being one } \\
\text { another's biggest fans. }\end{array}$ \\
\hline Didn't meet up much over the summer & $\begin{array}{l}\text { 2. Create the right environment physically and } \\
\text { emotionally to perform to your best. }\end{array}$ \\
\hline $\begin{array}{l}\text { The last few weeks were a pragmatic denial of what } \\
\text { was about to happen }\end{array}$ & $\begin{array}{l}\text { 3. Establish solid foundations up front about setting } \\
\text { up and ending the job share. }\end{array}$ \\
\hline A year later felt less guilty, didn't go back for a year & $\begin{array}{l}\text { 2. Create the right environment physically and } \\
\text { emotionally to perform to your best. }\end{array}$ \\
\hline Divorce was at least an amicable separation & $\begin{array}{l}\text { 3. Establish solid foundations up front about setting } \\
\text { up and ending the job share. }\end{array}$ \\
\hline
\end{tabular}

\section{References}

Acker, Joan. 1990. Hierarchies, jobs, bodies: A theory of gendered organisations. Gender and Society 4: 139-58. [CrossRef]

Alves, Freddie. 2016. The Eyes of the Manager. London: Flexible Boss, Available online: https://flexibleboss.com/ 2016/07/14/in-the-eyes-of-the-manager/ (accessed on 12 April 2019).

Black, C., and A. Islam. 2014. Women in Academia: What Does It Take to Reach the Top? The Guardian. Available online: http://www.theguardian.com/higher-education-network/blog/2014/feb/24/ women-academia-promotion-Cambridge (accessed on 10 April 2019).

Burkinshaw, Paula, and Kate White. 2017. Fixing the Women or Fixing Universities: Women in HE Leadership. Administrative Sciences 7: 30. [CrossRef]

Cannon, Fiona, and Nicky Elford. 2017. The Agility Mindset: How Reframing Flexible Working Delivers Competitive Advantage. New York: Palgrave Macmillan.

Chesterman, Colleen, Anne Ross-Smith, and Margaret Peters. 2003. Changing the Landscape? Women in Academic Leadership in Australia. McGill Journal of Education 38: 421-36. Available online: http: //hdl.handle.net/10453/12880 (accessed on 12 April 2019).

Clandinin, D. Jean, and Michael F. Connelly. 2000. Narrative Inquiry: Experience and Story in Qualitative Research. San Francisco: Jossey-Bass A Wiley Imprint.

Coleman, Marianne. 2011. Women at the Top: Challenges, Choices and Change. Hampshire: Palgrave Macmillan.

Coleman, Marianne. 2012. Leadership and diversity. Educational Management Administration E Leadership 40: 592-609.

Cunliffe, Ann. 2002. Reflexive Dialogical Practice in Management Learning. Management Learning 33: $35-61$. [CrossRef]

Daniels, Linda. 2011. Job Sharing at a Senior Level: Making It Work. The Job Share Project. Available online: www.thejobshareproject.com (accessed on 12 April 2019).

Daniels, Kevin, and Andrew Guppy. 1994. An exploratory study of stress in a British University. Higher Education Quarterly 48: 135-44. [CrossRef]

Eagly, Alice H., and Linda L. Carli. 2007. Through the Labyrinth: The Truth about How Women Become Leaders. Boston: Harvard Business School Publishing.

Elmuti, Dean, Heather Jia, and Henry H. Davis. 2009. Challenges Women Face in Leadership Positions and Organizational Effectiveness. Journal of Leadership Education 8: 167-87. [CrossRef]

Fereday, Jennifer, and Eimear Muir-Cochrane. 2006. Demonstrating Rigor Using Thematic Analysis: A Hybrid Approach of Inductive and Deductive Coding and Theme Development. International Journal of Qualitative Methods 5. [CrossRef] 
Fitzsimmons, Terrance W., Victor J. Callan, and Neil Paulsen. 2014. Gender disparity in the C-Suite: Do male and female CEOs differ in how they reached the top? The Leadership Quarterly 25: 245-66. [CrossRef]

Floersch, Jerry, Jeffrey L. Longhofer, Derrick Kranke, and Lisa Townsend. 2010. Integrating Thematic, Grounded Theory and Narrative Analysis A Case Study of Adolescent Psychotropic Treatment. Qualitative Social Work 9: 407-25. [CrossRef]

Gatrell, Caroline, and Elaine Swan. 2008. Gender and Diversity in Management, a Concise Introduction. London: Sage.

Heilman, Madeline E. 2001. Description and prescription: How gender stereotypes prevent women's ascent up the organizational ladder. Journal of Social Issues 57: 657-74. [CrossRef]

Higher Education Statistical Agency (HESA). 2017. HE Staff Statistics. Available online: https://www.hesa.ac.uk/ news/28-02-2019/staff-open-data-release (accessed on 5 June 2019).

Hoskins, Kate. 2013. Senior Female Academics in the UK Academy: Theoretical Perspectives for Understanding the Impact of Education and Familial Influences on Career Success. International Studies in Sociology of Education 23: 56-75. [CrossRef]

Hoyt, Crystal L. 2010. Women, men and leadership: Exploring the gender gap at the top. Social and Personality Psychology Compass 4: 484-98. [CrossRef]

Hoyt, Crystal L., and Stefanie K. Johnson. 2011. Gender and leadership development: A case of female leaders. In Early Development and Leadership: Building the Next Generation of Leaders. Edited by Susan E. Murphy and Rebecca Reichard. New York: Routledge, pp. 205-28.

Jackson, Brad, and Ken Parry. 2011. A Very Short, Fairly Interesting and Reasonably Cheap Book about Studying Leadership, 2nd ed. London: Sage.

Jarboe, N. 2016. WomenCount: Australian Universities 2016. Available online: https://women-count.org/portfolio/ womencount-australian-universities-2016/ (accessed on 8 June 2019).

Jarboe, N. 2018. WomenCount: Leaders in Higher Education 2018. Available online: https://womencountblog.files. wordpress.com/2018/11/womencount-report-2018_web-version_new-final.pdf (accessed on 8 June 2019).

Johnson, Heather L. 2017. Pipelines, Pathways, and Institutional Leadership: An Update on the Status of Women in Higher Education. Washington: American Council on Education.

Johnson, Z., and Babita Mathur-Helm. 2011. Experiences with Queen Bees: A South African Study Exploring the Reluctance of Women Executives to Promote Other Women in the Workplace. South African Journal of Business Management 42: 47-55.

Kempster, Steve. 2009. How Managers Have Learnt to Lead: Exploring the Development of Leadership Practice. Basingstoke: Palgrave Macmillan.

Kempster, Steve, and James Stewart. 2010. Becoming a leader: A co-produced autoethnographic exploration of situated learning of leadership practice. Management Learning 41: 205-19. [CrossRef]

Kermode, Frank. 1980. Secrets and Narrative Sequence. Critical Inquiry 7: 83-101. [CrossRef]

Leslie, Keith, Kathy Colgan, and Joel Bellman. 2016. Driving Transformation: Lessons for the Public Sector. Available online: https://www2.deloitte.com/content/dam/Deloitte/uk/Documents/public-sector/deloitte-ukps-driving-transformation.pdf (accessed on 3 June 2019).

Manfredi, Simonetta, Louise Grisoni, Karen Handley, Rebecca Nestor, and Felicity Cooke. 2014. Gender and Higher Education Leadership: Researching the Careers of Top Management Programme Alumni. London: Leadership Foundation for Higher Education, Available online: http://www.ecu.ac.uk/wp-content/uploads/2014/07/ Manfredi-gender-top-management-alumni-final-report.pdf (accessed on 12 April 2019).

Mintzberg, Henry. 1989. Mintzberg on Management: Inside Our Strange World of Organizations. New York: The Free Press.

Morley, Louise. 2013. The rules of the game: Women and the leaderist turn in higher education. Gender and Education 25: 116-31. [CrossRef]

Morley, Louise. 2014. Lost Leaders: Women in the Global Academy. Higher Education Research E Development 33: 114-28. [CrossRef]

Northouse, Peter G. 2007. Leadership Theory and Practice, 4th ed. Thousand Oaks: Sage Publications.

Parsons, Elizabeth, and Vincenza Priola. 2010. The micro-politics of feminism in the managerial university. Paper presented at the Gender, Work and Organisation Conference, Staffordshire, UK, June 21-23.

Redmond, Petrea, Hannah Gutke, Linda Galligan, Angela Howard, and Tara Newman. 2017. Becoming a female leader in higher education: Investigations from a regional university. Gender and Education 29: 332-51. [CrossRef] 
Reid, Wendy, and Rekha Karambayya. 2009. Impact of dual executive leadership dynamics in creative organizations. Human Relations 62: 1073-112. [CrossRef]

Rollick, Nicola. 2019. Staying Power: The Career Experiences and Strategies of UK Black Female Professors. Report by the University and College Union. Available online: https://www.ucu.org.uk/media/10075/stayingpower/pdf/ucu_rollock_february_2019.pdf (accessed on 8 June 2019).

Saunders, Andrew, and Kate Bassett. 2017. The power of the pair. Management Today, 36-40.

Sealy, Ruth, Elena Doldor, and Susan Vinnicombe. 2016. The Female FTSE Board Report 2016: Women on Boards: Taking Stock Of Where We Are. Available online: file://C:/Users/watton/AppData/Local/Packages/Microsoft. MicrosoftEdge_8wekyb3d8bbwe/TempState/Downloads/Female\%20FTSE\%20Board\%20Report\%202016\% 20(1).pdf (accessed on 8 June 2019).

Shakeshaft, Charol, Genevieve Brown, Beverly Irby, Margaret Grogan, Ballenger Julia, and Susan S. Klein. 2007. Increasing Gender Equity in Educational Leadership. In Handbook for Achieving Gender Equity through Education, 2nd ed. Edited by Susan S. Klein, Barbara Richardson, Dolres A. Graywon, Lynn H. Fox, Cheris Kramarae, Diane S. Pollard and Carol A. Dwyer. New York: Routledge, pp. 103-29.

Shepherd, Sue. 2015. Appointing Deputy and Provice Chancellors in Pre-1992 English Universities: Managers, Management and Managerialism. Unpublished Ph.D. thesis, University of Kent, Kent, UK.

Shepherd, Sue. 2017. Why are there so few female leaders in higher education: A case of structure or agency? Management in Education 31: 82-87. [CrossRef]

Sidaway, J., and A. Wareing. 1992. Part-timers with potential. Employment Gazette, January 19-26.

Sinclair, Amanda. 2007. Leadership for the Disillusioned: Moving Beyond Myths and Heroes to Leading That Liberates. Crows Nest: Allen \& Unwin.

Stead, Valerie. 2013. Learning to deploy (in)visibility: An examination of women leaders' lived experiences. Management Learning 44: 63-79. [CrossRef]

Stead, Valerie, and Carole J. Elliott. 2009. Women's Leadership. Basingstoke: Palgrave Macmillan.

Talking Talent. 2015. Up, Out or Different?: The Career Dilemma for UK Women. Available online: https: //www.talking-talent.com/ (accessed on 12 April 2019).

Talking Talent. 2018. Gender Equality Needs a New Deal for Dad's at Work. Available online: https://www. talking-talent.com/en/gender-equality-needs-new-deal-dads-work (accessed on 12 April 2019).

Taylor, Judy. 2013. Gender Diversity in the Healthcare Sector-How Much Progress Have We Made? The Kings Fund. Available online: http://www.kingsfund.org.uk/ (accessed on 30 March 2014).

Thakur, Mahima, Anjali Bansal, and Rashmi Maini. 2018. Job sharing as a tool for flexible work systems: Creating opportunities for housewives in the Indian labor market. Gender in Management: An International Journal 33: 350-66. [CrossRef]

The Gender Equality Taskforce. 2018. Accelerating Gender Equality in Irish Higher Education Institutions-Gender Action Plan 2018-2020. Available online: https://hea.ie/assets/uploads/2018/11/Gender-Equality-TaskforceAction-Plan-2018-2020.pdf (accessed on 8 June 2019).

Thude, Bettina Ravnborg, Svend Erik Thomsen, Egon Stenager, and Erik Hollnagel. 2017. Dual leadership in a hospital practice. Leadership in Health Services 30: 101-12. [CrossRef] [PubMed]

Vinnicombe, Sue, Elena Doldor, and Ruth Sealy. 2018. The Female FTSE Board Report 2018: Busy Going Nowhere with the Female Executive Pipeline. Available online: http://business-school.exeter.ac.uk/ media/universityofexeter/businessschool/documents/research/Female_FTSE_Report_2018.pdf (accessed on 12 April 2019).

Walton, Pam. 1990. Job Sharing: A Practical Guide. London: Kogan Page.

White, Kate, Theresa Carvalho, and Sarah Riordan. 2011. Gender, Power and Managerialism in Universities. Journal of Higher Education Policy and Management 33: 179-86. [CrossRef]

Williams, Kelly. 2000. Time for change? Office Solutions 17: 16-18.

Working Families. 2007. Hours to Suit: Working Flexibly at Senior and Managerial Levels. Available online: http://www.workingfamilies.org.uk/publications/hours-to-suit-working-flexibly-at-senior-andmanagerial-levels/ (accessed on 12 April 2019).

(C) 2019 by the authors. Licensee MDPI, Basel, Switzerland. This article is an open access article distributed under the terms and conditions of the Creative Commons Attribution (CC BY) license (http://creativecommons.org/licenses/by/4.0/). 